\title{
Physico-Chemical Properties of Soils in Lviv Volyn Coal Basin Area
}

\author{
Vasyl Popovych ${ }^{1}$, Kateryna Stepova ${ }^{1},{ }^{*}$, Andriy Voloshchyshyn ${ }^{1}$, and Pavlo Bosak ${ }^{1}$ \\ ${ }^{1}$ Lviv State University of Life Safety, 79000, 35 Kleparivaska str., Lviv, Ukraine
}

\begin{abstract}
The results of the research showed that hydromorphous soils prevail on the territories adjoined to waste heaps. Swampy meadow and sod soils were defined. During investigation of swampy meadow soils it was determined that the soil is humused at a considerable depth. The soils are saturated with the bases. According to granulometric texture it is sandy loam soils, but with depth go to the middle loamy soils. The analysis for labile forms of heavy metals showed that in these soils the content of investigated heavy metals does not exceed the maximum allowable concentrations, except for lead. The amount of humus in sod soils sharply decreases with depth, the reaction is close to neutral. This soil is of slightly heavier granulometric texture. The content of labile forms of heavy metals doesn't exceed MACs, except for lead.
\end{abstract}

\section{Introduction}

Lviv-Volyn coal basin was created for over 60 years ago in one of the best places in Western Ukraine - the recreation zone. Novovolynsk mining area is located in the northern part of the basin and is one of the most environmentally problematic areas.

Ecological and hydrogeochemical studies of the surface content of the waste heaps of the Novovolynsk mining area are described in papers [1, 2]. A number of recommendations for recultivation of disturbed lands in coal mining regions were developed [3-5]. Modeling of variability and heterogeneity of physical and mechanical properties of rocks and rock mass for the optimal technological solutions during dumps formation and their design were carried out [6].

Exploration, extraction, processing and use of mineral resources is accompanied by irreversible direct and indirect changes in the environment, which leads to the formation of disturbed lands of different types, scales and genesis [7, 8].

The soils conditions on the territory of the Lviv-Volyn coal basin depends on the natural factors of the Volyn Forest-Steppe and Male Polissya. Thus, the soil-forming rocks of both the Forest-Steppe and the Western Polissya influenced the formation of these soils.

The Volyn Forest-Steppe soils, geobotanically, belong to the platyphyllous Eastern European region. The Volyn Forest-Steppe covers the Volyn Highland, which is bounded on the east by the left bank of the Goryn River, from the west by the Bug River valley, and

\footnotetext{
*Corresponding author: katyastepova@gmail.com
} 
in the north and south it passes through well-defined benches in Volyn and Male Polissya, respectively.

In order to investigate the influence of the rock of waste heaps on the formation of the profile of the soils of the Novovolynsk mining area, soil profiles were uncovered, from which mixed soil samples from genetic horizon were taken and chemical analyzes were carried out.

\section{Materials and Methods}

The granulometric composition of the soil was determined by the Kachinsky method, with the preparation by the pyrophosphate method; humus content - by Tyurin's method in Nikitin's modification; $\mathrm{pH}$ of water and salt extract - by potentiometry; hydrolytic acidity and the amount of absorbed bases - by the Kappen method; the degree of basics saturation - by the calculation; exchangeable calcium and magnesium - by complexometric method; easily hydrolizabled nitrogen - by the Cornfield method; labile potassium - by methods of Chirikov (not carbonate samples) and Protasova (carbonate samples); labile phosphorus by the methods of Chirikov (not carbonate samples) and Machigin (carbonate samples); $\mathrm{CO}_{2}$ of carbonates - calcimetery by the method Geysler-Maksymyuk; labile copper, zinc, cobalt were determined by the method of Rinkis, lead, cadmium - by atomic absorption method. Field studies of soils were conducted in accordance with the "Instructions for the soils examination of Ukraine" [9]. The description of the genetic horizons was carried out according to [10].

\section{Results and Discussion}

The results of the research showed that hydromorphous soils prevail on the territories adjoined to waste heaps. The reason for their formation is the poor drainage that causes the local water saturation of the area.

Swampy meadow and sod soils were defined. During investigation of swampy meadow soils (soil profile 1) it was determined that the soil is humused at a considerable depth (up to $80 \mathrm{~cm}$ ), the content of humus at this depth is $1.75 \%$ (Table 1), and at a depth of $102 \mathrm{~cm}$ the amount goes down to $0.36 \%$.

Table 1. Physico-chemical properties of swampy meadow soil (soil profile 1).

\begin{tabular}{|c|c|c|c|c|c|c|c|c|c|c|}
\hline \multirow{2}{*}{$\begin{array}{c}\text { The } \\
\text { depth } \\
\text { of } \\
\text { sampli } \\
\text { ng, cm }\end{array}$} & \multirow{2}{*}{$\begin{array}{l}\text { Genetic } \\
\text { horizon }\end{array}$} & \multirow{2}{*}{$\begin{array}{c}\text { Hum } \\
\text { us, } \\
\%\end{array}$} & \multicolumn{2}{|c|}{ pH } & $\begin{array}{c}\text { hydrol } \\
\text { ytic }\end{array}$ & $\begin{array}{l}\text { total } \\
\text { absor } \\
\text { bed }\end{array}$ & \multirow{2}{*}{$\begin{array}{c}\text { percent } \\
\text { age of } \\
\text { base } \\
\text { saturati } \\
\text { on, } \%\end{array}$} & $\begin{array}{l}\mathrm{Ca} \\
2+\end{array}$ & $\begin{array}{c}\mathbf{M g} \\
2+\end{array}$ & \multirow{2}{*}{$\begin{array}{c}\mathrm{CaC} \\
\mathrm{O3} \\
\text { conte } \\
\text { nt, \% }\end{array}$} \\
\hline & & & $\begin{array}{c}\text { sali } \\
\text { ne }\end{array}$ & $\begin{array}{l}\text { aque } \\
\text { ous }\end{array}$ & \multicolumn{2}{|c|}{$\begin{array}{c}\text { mg-equ/100 } \mathrm{g} \text { of } \\
\text { soil }\end{array}$} & & \multicolumn{2}{|c|}{$\begin{array}{c}\text { mg- } \\
\text { equ/100 } \mathrm{g} \\
\text { of soil }\end{array}$} & \\
\hline $\begin{array}{c}0-20 \\
20\end{array}$ & $\mathrm{H}$ (plow) & 3.05 & 5.50 & 6.60 & 3.40 & 13.30 & 63.33 & 12.60 & 8.40 & UND \\
\hline $\begin{array}{c}20-33 \\
13 \\
\end{array}$ & $\begin{array}{l}\text { H(subsurf } \\
\text { ace) }\end{array}$ & 2.59 & 5.62 & 6.29 & 2.45 & 10.60 & 81.23 & 10.40 & 7.20 & UND \\
\hline $\begin{array}{c}60-80 \\
20\end{array}$ & $\mathrm{P}(\mathrm{h})(\mathrm{gl})$ & 1.75 & 6.72 & 6.90 & 0.79 & 24.00 & 96.81 & 19.60 & 6.40 & UND \\
\hline $\begin{array}{c}102-112 \\
10\end{array}$ & Pkgl & 0.36 & 6.8 & 7.78 & UND & UND & UND & UND & UND & 2.05 \\
\hline
\end{tabular}


The distribution of humus content on the soil profile is gradual. The reaction of the soil ground is weakly acidic, that tends to neutral $(\mathrm{pH}=5.5-6.7)$ with depth. Hydrolytic acidity is low. The soils are saturated with the bases. The saturation index increases to full saturation with the depth in the transition horizon (at a depth of $80 \mathrm{~cm}$, it is $96.81 \%$ ).

According to granulometric texture it is sandy loam soils (Table 2), but with depth go to the middle loamy soils. At a depth of $80 \mathrm{~cm}$, the physical clay content is $35.6 \%$. Parent rock (depth more than $100 \mathrm{~cm}$ ) is sandy loam soil, the content of physical clay is $19.08 \%$. This soil was formed on gley rock made up of greyish/blueish colours inside the peds with manganese inclusions.

Table 2. Granulometric texture swampy meadow soil (soil profile 1).

\begin{tabular}{|c|c|c|c|c|c|c|c|c|c|}
\hline \multirow{4}{*}{$\begin{array}{c}\text { The } \\
\text { depth of } \\
\text { sampling, } \\
\text { cm }\end{array}$} & \multirow{4}{*}{$\begin{array}{c}\text { Genetic } \\
\text { horizon }\end{array}$} & \multicolumn{6}{|c|}{ Particle size in $\mathrm{mm}$, quantity \% } & \multirow{4}{*}{$\begin{array}{l}\text { Amount } \\
\text { of } \\
\text { particles } \\
\text { less then } \\
0.01 \mathrm{~mm}\end{array}$} & \multirow{4}{*}{$\begin{array}{c}\text { Type by } \\
\text { granulome } \\
\text { tric } \\
\text { texture }\end{array}$} \\
\hline & & \multicolumn{2}{|c|}{ physical sand } & \multicolumn{4}{|c|}{ physical clay } & & \\
\hline & & sand & & & & & clay & & \\
\hline & & $1-0.25$ & $\begin{array}{c}0.25- \\
0.05\end{array}$ & $\begin{array}{c}0.05- \\
0.01\end{array}$ & \begin{tabular}{l|}
$0.01-$ \\
0.005
\end{tabular} & $\begin{array}{l}0.005- \\
0.001\end{array}$ & $<0.001$ & & \\
\hline$\frac{0-20}{20}$ & $\mathrm{H}$ (plow) & 4.35 & 12.30 & 56.69 & 1.40 & 10.60 & 1.40 & 12.50 & sandy loam \\
\hline$\frac{20-33}{13}$ & $\begin{array}{c}\mathrm{H} \\
\text { (subsurfa } \\
\text { ce) }\end{array}$ & 4.40 & 15.88 & 63.32 & 1.48 & 12.52 & 2.40 & 16.40 & sandy loam \\
\hline$\frac{60-80}{20}$ & $\mathrm{P}(\mathrm{h})(\mathrm{gl})$ & 4.40 & 15.28 & 44.76 & 4.92 & 6.92 & 23.72 & 35.56 & $\begin{array}{c}\text { middle } \\
\text { loamy soils }\end{array}$ \\
\hline$\frac{102-112}{10}$ & Pkgl & 29.60 & 31.56 & 19.76 & 10.60 & 3.68 & 4.80 & 19.08 & sandy loam \\
\hline
\end{tabular}

The analysis for labile forms of heavy metals showed that in these soils the content of investigated heavy metals does not exceed the maximum allowable concentrations (MACs) except for lead. The content of such an acute pollutant as cadmium in these soils is one order less than the accepted standards. The distribution of labile forms of heavy metals in the soils profile gradually decreases with depth. The highest content of metals is found in the humus horizon, except for cobalt and cadmium. Decrease of humus content with depth causes the increase of $\mathrm{Co}$ and $\mathrm{Cd}$ content. (Table 3).

Table 3. Labile forms of heavy metals in swampy meadow soil (soil profile 1).

\begin{tabular}{|c|c|c|c|c|c|c|c|c|}
\hline $\begin{array}{c}\text { The } \\
\text { depth of } \\
\text { sampling, } \\
\text { cm } \\
\end{array}$ & $\begin{array}{l}\text { Genetic } \\
\text { horizon }\end{array}$ & $\underset{\%}{\text { Humus, }}$ & $\begin{array}{c}\mathrm{Fe}_{2} \mathrm{O}_{3}, \\
\mathrm{mg} / \mathbf{1 0 0} \\
\quad \mathrm{g}\end{array}$ & $\begin{array}{c}\mathrm{Cu}, \\
\mathrm{mg} / \mathrm{kg}\end{array}$ & $\begin{array}{c}\mathrm{Zn}, \\
\mathrm{mg} / \mathrm{kg}\end{array}$ & $\begin{array}{c}\mathrm{Pb}, \\
\mathrm{mg} / \mathrm{kg}\end{array}$ & $\begin{array}{c}\mathrm{Co}, \\
\mathrm{mg} / \mathrm{kg}\end{array}$ & $\begin{array}{c}\mathrm{Cd}, \\
\mathrm{mg} / \mathrm{kg}\end{array}$ \\
\hline$\frac{0-20}{20}$ & H(plow) & 3.05 & 105.5 & 0.93 & 12.2 & 3.2 & 0.9 & 0.02 \\
\hline$\frac{20-33}{13}$ & $\mathrm{H}$ (subsurface) & 2.59 & 108.6 & 0.87 & 11.8 & 3.0 & 1.0 & 0.04 \\
\hline$\frac{60-80}{20}$ & $\mathrm{P}(\mathrm{h})(\mathrm{gl})$ & 1.75 & 200.2 & 0.69 & 5.03 & 2.7 & 1.1 & 0.06 \\
\hline$\frac{102-112}{10}$ & Pkgl & 0.36 & 68.6 & 0.77 & 4.53 & 2.9 & 1.2 & 0.05 \\
\hline \multicolumn{2}{|c|}{ Profile MAC } & - & - & 3 & 23 & 2 & 5 & 0.7 \\
\hline
\end{tabular}


The study of sod soil (soil profile 2) formed under less moistened conditions showed that it has different physico-chemical characteristics. It formed on the sandy loess loam and contains less organic substances than meadow soils. The amount of humus sharply decreases with depth, the reaction is close to neutral ( $\mathrm{pH}$ is 6.4$)$, the hydrolytic acidity is very low confirming the neutral reaction of these soils. The sod soils have a total absorbed basis of $91.21 \%$ (Table 4$)$.

Table 4. Physico-chemical properties of sod soil (soil profile 2).

\begin{tabular}{|c|c|c|c|c|c|c|c|c|c|c|}
\hline $\begin{array}{c}\text { The } \\
\text { depth of } \\
\text { sampling }\end{array}$ & $\begin{array}{l}\text { Genetic } \\
\text { horizon }\end{array}$ & $\begin{array}{c}\text { Hum } \\
\text { us, } \\
\%\end{array}$ & pl & & $\begin{array}{l}\text { hydroly } \\
\text { c acidit }\end{array}$ & $\begin{array}{c}\text { total } \\
\text { absorbed } \\
\text { bases }\end{array}$ & $\begin{array}{c}\text { percenta } \\
\text { ge of } \\
\text { base }\end{array}$ & $\mathrm{Ca}^{2+}$ & $\mathrm{Mg}^{2+}$ & $\begin{array}{c}\mathrm{CaCO}_{3} \\
\text { content, } \\
\%\end{array}$ \\
\hline, $\mathrm{cm}$ & & & saline & \begin{tabular}{|c|} 
aqueo \\
us
\end{tabular} & mg-eq & $\begin{array}{l}100 \mathrm{~g} \text { of } \\
\text { il }\end{array}$ & $\begin{array}{c}\text { saturatio } \\
\text { n, \% }\end{array}$ & mg-eq & $g$ of & \\
\hline $\begin{array}{c}3-13 \\
10 \\
\end{array}$ & $\mathrm{H}$ & 2.02 & 6.37 & 6.58 & 1.31 & 13.60 & 91.21 & 12.40 & 6.00 & UND \\
\hline $\begin{array}{c}35-45 \\
10\end{array}$ & $\mathrm{P}(\mathrm{h})$ & 1.14 & UND & 7.49 & UND & UND & UND & UND & UND & 0.82 \\
\hline $\begin{array}{c}60-80 \\
20\end{array}$ & Pkgl & 1.04 & UND & 7.96 & UND & UND & UND & UND & UND & 13.12 \\
\hline
\end{tabular}

This soil is of slightly heavier granulometric texture. It is sandy loam (the content of physical clay at a depth of $20 \mathrm{~cm}$ is $20.88 \%$ ). It transforms with a depth (the first transition horizon) into medium-textured loam (the content of physical clay is $33.72 \%$ ) (Table 5). The parent rock is gleyish, carbonate (high content of $\mathrm{CaCO}_{3}$ ). Indicators of the physical and chemical properties of the soil confirm its contamination by emissions of coal extraction waste.

Table 5. Granulometric texture of sod soil (soil profile 2).

\begin{tabular}{|c|c|c|c|c|c|c|c|c|c|}
\hline \multirow{4}{*}{$\begin{array}{l}\text { The depth } \\
\text { of } \\
\text { sampling, } \\
\text { cm }\end{array}$} & \multirow{4}{*}{$\begin{array}{l}\text { Genetic } \\
\text { horizon }\end{array}$} & \multicolumn{6}{|c|}{ Particle size in $\mathrm{mm}$, quantity \% } & \multirow{4}{*}{\begin{tabular}{|c|} 
Amount of \\
particles less \\
then $0.01 \mathrm{~mm}$
\end{tabular}} & \multirow{4}{*}{$\begin{array}{c}\text { Type by } \\
\text { granulometric } \\
\text { texture (by } \\
\text { Kachinsky) }\end{array}$} \\
\hline & & \multicolumn{2}{|c|}{ physical sand } & \multicolumn{4}{|c|}{ physical clay } & & \\
\hline & & sand & \multicolumn{4}{|c|}{ dust } & \multirow{2}{*}{\begin{tabular}{|l|} 
sand \\
$<0.001$ \\
\end{tabular}} & & \\
\hline & & $1-0.25$ & $\begin{array}{l}0.25- \\
0.05\end{array}$ & $\begin{array}{l}0.05- \\
0.01\end{array}$ & $\begin{array}{l}0.01- \\
0.005\end{array}$ & \begin{tabular}{|c|}
$0.005-$ \\
0.001 \\
\end{tabular} & & & \\
\hline $\begin{array}{c}3-13 \\
10\end{array}$ & $\mathrm{H}$ & 3.20 & 8.24 & 67.68 & 5.88 & 13.16 & 1.84 & 20.88 & sandy loam \\
\hline $\begin{array}{c}35-45 \\
10\end{array}$ & $\mathrm{P}(\mathrm{h})$ & 1.20 & 8.68 & 56.40 & 5.24 & 3.44 & 25.04 & 33.72 & $\begin{array}{c}\text { medium-textured } \\
\text { loam }\end{array}$ \\
\hline $\begin{array}{c}60-80 \\
20\end{array}$ & Pkgl & 0.40 & 14.72 & 59.44 & 1.48 & 17.60 & 6.36 & 25.44 & sandy loam \\
\hline
\end{tabular}

Regarding the labile forms of heavy metals, no increase in the content of heavy metals, except for lead (Table 6) was indicated.

However, there is a tendency to lead content increase in the upper humus horizon - 0.5 $\mathrm{mg} / \mathrm{kg}$ of soil. Down to sod soils profile this increase goes a bit up - to $1 \mathrm{mg} / \mathrm{kg}$. This growth is explained by the decrease in the gleyiness of the lower horizons of sod soils. So at a depth of more than $60 \mathrm{~cm}$ the content decreases again with the appearance of gley processes in flooding of the soil. 
Table 6. Labile forms of heavy metals in sod soil (soil profile 2).

\begin{tabular}{|c|c|c|c|c|c|c|c|c|}
\hline $\begin{array}{c}\text { The } \\
\text { depth of } \\
\text { sampling, } \\
\mathbf{c m}\end{array}$ & $\begin{array}{c}\text { Genetic } \\
\text { horizon }\end{array}$ & $\begin{array}{c}\text { Humus, } \\
\mathbf{\%}\end{array}$ & $\begin{array}{c}\mathrm{Fe}_{2} \mathbf{O}_{3}, \\
\mathbf{m g} / \mathbf{1 0 0} \\
\mathbf{g}\end{array}$ & $\begin{array}{c}\mathbf{C u}, \\
\mathbf{m g} / \mathbf{k g}\end{array}$ & $\begin{array}{c}\mathbf{Z n}, \\
\mathbf{m g} / \mathbf{k g}\end{array}$ & $\begin{array}{c}\mathbf{P b}, \\
\mathbf{m g} / \mathbf{k g}\end{array}$ & $\begin{array}{c}\mathbf{C o}, \\
\mathbf{m g} / \mathbf{k g}\end{array}$ & $\begin{array}{c}\mathbf{C d}, \\
\mathbf{m g} / \mathbf{k g}\end{array}$ \\
\hline $\begin{array}{c}3-13 \\
10\end{array}$ & $\mathrm{H}$ & 2.02 & 114.4 & 0.59 & 5.14 & 2.5 & 1.1 & 0.04 \\
\hline $\begin{array}{c}35-45 \\
10\end{array}$ & $\mathrm{P}(\mathrm{h})$ & 1.14 & 157.3 & 0.77 & 4.02 & 2.8 & 1.0 & 0.08 \\
\hline $\begin{array}{c}60-80 \\
20\end{array}$ & $\mathrm{Pkgl}$ & 1.04 & 82.94 & 2.04 & 8.25 & 2.6 & 1.3 & 0.07 \\
\hline \multicolumn{2}{|c|}{ Profile MAC } & - & - & 3 & 23 & 2 & 5 & 0.7 \\
\hline
\end{tabular}

\section{Conclusion}

The risk of man-made soil contamination by heavy metals is that it may not manifest itself for a long time, due to the buffering properties of soils, and be a significant factor in the negative transformations of both the soil as a whole and its individual components.

In the investigated soils the iron oxides content is high in the middle (eluvial) horizons and decreases when coming close to the parent rock. It is caused by the podzolization (the destruction of aluminosilicates and the movement of their products to the lower horizons).

The heavy metals content in soil profiles is uneven due to violation of genetic horizons, changes in acidity, inhibition of elements cycle and significant man-made effect during the operation of mines. Low absorption capacity and porosity of soils lead to the washing of heavy metals to the parent rock.

\section{References}

1. U.B. Bashutska, Sc. Bul. UNFU, 10:2, 61-63 (2000)

2. O. Tereshchuk, Bul. Lviv Univ. Geog., 34, 279-285 (2007)

3. V.M. Zverkovsky, Ukr. Bot. J., 54:5, 474-481 (1997)

4. Yu.A. Manakov, Eco-bul. InEkA, 4, 29-33 (2008)

5. Yu.A. Manakov, Kuzbas, 44, 2-3 (2006)

6. N.G. Maksymovych, V. Perm Univ. Geol., 4, 171-185 (1997)

7. V. Popovych, O. Kuzmenko, A. Voloshchyshyn, M. Petlovanyi, E3S Web Conf., 60, 00010 (2018)

8. M. Petlovanyi, MMD, 13:1, 24-38 (2019)

9. Instructions on the examination of soils of Ukraine (Pochvi, Kharkiv, 1957)

10. N.K. Krupsky, Atlas of soils of the Ukrainian SSR (Urozhai, Kiev, 1979) 